\title{
The Nature of Fluid in Strike-slip Faults, Shunbei ultra-deep Oil Field, Tarim Basin
}

DONGHUA YOU ${ }^{1 *}$, ZICHENG CAO ${ }^{2}, \mathrm{JUN} \mathrm{HAN}^{2}$, YIXIONG QIAN $^{1}$, QIANGLU CHEN ${ }^{1}$

${ }^{1}$ Petroleum Exploration and Production Research Institute of SINOPEC, Beijing, China (*correspondence: youdh.syky@sinopec.com)

${ }^{2}$ Exploration and Development Research Institute, Northwest Oilfield Company of SINOPEC, Urumqi, China.

More than $1,500,000$ tons $(9.4$ million bbl $)$ of accumulated crude oil, which are mainly produced from strike-slip fault zone in the Middle-Lower Ordovician limestone, come from a depth greater than $7200 \mathrm{~m}$ subsurface of the Shunbei ultra-deep oilfield in the Tarim Basin since 2016 [1-3]. Based on high-quality three-dimension seismic data, the precise interpretation of strike-slip faults has become an important basis for drilling deployment. There has been much speculation as to whether there was any fluid activity in the strike-slip fault zone and whether it contributed to the formation of reservoir space. The detailed analysis (such as computed tomography, photograph, fluid inclusion, carbon and oxygen isotope, strontium isotopes, and pyrite sulfur isotopes) of typical samples obtained from the strikeslip fault zone were carried out. We believe that there were hydrothermal fluids and low-temperature fluids in subsurface strike-slip faults, and the fluid-rock interaction process in them helped the formation of reservoir space. Comparative analysis of calcite cement from different wells shows that the fluids moving in the fault zone may (partly) originate from deep circulating fluids that have infiltrated along the fault zone in the northern karst highlands. Stratigraphic warming and volcanic activity (intermediate-basic volcanic rocks subvolcanic rocks found in Yingshan Formation) may be an important heat source driving mechanisms. Therefore, we hypothesized a geological model of fluid action fed by meteoric water in the strike-slip fault zone.

[1] Deng et al. (2019) AAPG Bulletin, 103(1), 109-137. [2] Ma et al. (2019) Earth Science, doi: 10.3799/dqkx.2019.157. [3] Jiao F. (2018) Oil \& Gas Geology, 39(2), 207-216.

Acknowledgments: This work was supported by the National Natural Science Foundation of China (U1663209, 41830425). 